\title{
Fit for Future Conflict? American Strategic Culture in the Context of Great Power Competition
}

\author{
Jeannie L. Johnson, PhD
}

\begin{abstract}
U.S. strategic planners seeking to achieve the upper hand in ongoing and future conflict with near-peer adversaries will derive significant advantages from a thorough understanding of American strategic culture and its inherent blind spots. Studied self-awareness will make it less likely that U.S. adversaries can exploit deficits in traditional U.S. defense practices and may inspire an investment in skills, tactics, and diplomatic approaches that innovate beyond the American strategic culture comfort zone. New U.S. strategies are needed in the current era of ideological competition driven by Russia and China's use of digital technologies to undermine democratic governance and grow the world market for data surveillance-based authoritarianism.
\end{abstract}

Keywords: strategic culture, future war, great power competition, cultural analysis, lessons learned, irregular war, information operations, digital authoritarianism, digital surveillance, Russia, China

\section{Introduction}

reat power competition across the early years of the twenty-first cen-
tury has been characterized by increasingly refined tools of subversive
statecraft. Future competition with U.S. adversaries, including war,

Jeannie L. Johnson is director of the Center for Anticipatory Intelligence (CAI) at Utah State University in Logan and an associate professor in the Political Science Department. She worked as an intelligence analyst from 1998 to 1999 and pioneered the Cultural Topography Framework with Matt Berrett, then the Central Intelligence Agency's assistant director for global issues. Dr. Johnson's primary research interest, strategic culture, examines the impact of national and organizational cultures on the formation of security policy. She has published several books employing the strategic culture methodology. This article was completed with the substantial editing assistance of Briana Bowen, CAI program manager.

$$
\begin{gathered}
\text { Journal of Advanced Military Studies vol. 11, no. } 1 \\
\text { Spring } 2020 \\
\text { www.usmcu.edu/mcupress } \\
\text { https://doi.org/10.21140/mcuj.2020110109 }
\end{gathered}
$$


will comprise a fast-evolving and wide-ranging arsenal of tactics aimed at circumventing U.S. power assets and undermining American influence on the world stage.

Successful engagement in twenty-first century great power competition, whether in combat zones or cyber arenas, will be substantially aided by a cleareyed understanding of the United States' traditional habits of mind and practice and the ways in which these stack up against the evolving strategies and operational devices of our adversaries. U.S. military and diplomatic toolkits are stocked with a number of reflexive problem solving devices, not all of which are a good fit with twenty-first century threats. Confronting the nimble, often indirect and unorthodox tactics of our enemies will require creativity and innovation. As U.S. adversaries advance against perceived vulnerabilities in our typical repertoire of security responses, outwitting them will require conscious scrutiny of our own internal habits of cognition and behavior.

The field of strategic culture examines the ways in which national public culture and the various organizational cultures of a country's defense, intelligence, and diplomatic institutions impact the formation of its foreign and security policy. The effectiveness of contemporary U.S. adversaries is enhanced by their studied understanding of American strategic culture-the ways in which both American national culture and the organizational cultures of the U.S. security community advance or inhibit innovative thinking; the range of policy actions perceived to be both effective and permissible; the order of action warfighters default to in approaching an enemy; and the acts below the threshold of war that are likely to stymie U.S. institutions that are left without a clear script for action. Near-peer competitors have already chalked up significant wins in the cyber domain, information operations, proxy warfare, and in expanding their own spheres of influence by exploiting weaknesses in the playbook of the American national security enterprise. ${ }^{1}$

To achieve the upper hand in twenty-first century great power competition, the U.S. defense establishment should seek to know the strengths and vulnerabilities of its own strategic culture at least as well as American adversaries who are actively studying it. Neglect of deliberate and careful cultural analysis -both of American cultural patterns and of the culturally patterned security reflexes of adversaries - will leave the United States two steps behind near-peer powers who have made it their business to understand the cultural narratives driving U.S. policy and the cultural norms shaping the thinking of populations that both the United States and its competitors seek to influence.

The bursts of investment in cultural analysis made by the U.S. defense establishment have tended to be in the midst of fighting wars rather than in advance of them and have not survived much past the termination of conflict. In recent years, the idea of cultural analysis has become curiously and 
unfortunately intertwined with that of counterinsurgent warfare. This is ironic given that the birth of strategic culture as a field of study came from scholarpractitioners who were crafting U.S. nuclear policy vis-à-vis the Soviet Union, then the superpower of the day. A giant of first-generation strategic culture scholarship, Colin S. Gray, observed dangerous deficits in U.S. cultural knowledge throughout the Cold War era. Although most U.S. policy makers recognized that the strategic behavior of adversaries (and allies) was culturally "different," that recognition only "very rarely moved the U.S. government in its conduct of affairs to take explicit account of the effects of those differences upon policy goals and methods." 2 Failure to do so meant poor policy decisions rooted in inaccurate and often mirror-image conceptions of adversary thinking and behavior. ${ }^{3}$ Serious investment of the sort Gray recommended-taking explicit account of cultural differences and their effects on policy goals and behavior-is the purpose of analyzing strategic culture.

American national culture combines features of identity, preferred templates for action, distinctive values, and perceptions of the world shaped by the American experience. The subculture of the U.S. military expands on and reinforces many dominant American traits and introduces some its own. This combination of strategic culture traits exists because they have rewarded the American community, or at least significant subcommunities, with success in formative moments of the national experience. Making sense of these salient traits within American strategic culture requires thorough study of the United States' unique history; and yields valuable insights on the future contexts of great power competition for which U.S. preferred action templates are, and are not, an effective match.

The particular features of American strategic culture discussed here represent habits of mind and behavior in the American way of life that have been identified with consistency by scholars, ethnographers, historians, and foreign observers of the American condition across the last 100 years of U.S. warfighting. ${ }^{4}$ The United States is characterized by a large and diverse population and houses myriad subcultures with distinct identities, norms, value orientations, and perceptions of the world. Some of the resulting cultural inclinations tend to weigh more heavily than others in American foreign and security policy decision making and in the habits of American warfighters across combat theaters. It is important to note that, while a given trait may qualify as being persistently within the American repertoire, its influence on thinking and behavior is likely to ebb and flow in response to contextual factors. This is key. Cultural influences do not provide a clear-cut script for action but do tend to bound our beliefs about the range of effective and appropriate options available in a given situation. For the purposes of military planning, the result can be strategically suboptimal: security practices and tactics that are a clear match with organizational 
or national identity and practice are privileged over potentially more effective policies that fall outside the strategic culture mainstream.

This article does not attempt to be comprehensive in cataloging the various features of American strategic culture or the full historical contexts from which they derive. Rather, the purpose is to critically examine a few cultural traits that have proven particularly problematic when applied to U.S. operations abroad and are likely to be exploited by great power competitors in the present and immediate future. Illuminating these traits serves at least three key purposes:

- Studied self-awareness makes it less likely that dedicated adversaries can exploit blind spots in American security thinking and action.

- Recognizing gaps in the U.S. strategic culture repertoireskills and competencies in which the United States has underinvested as a consequence of investing in preferred modes of action-may prompt budget and training shifts to address those gaps.

- Clearly identifying the cultural roots of some preferred security practices may prompt strategic planners to reexamine their effectiveness and suitability with increased scrutiny before applying them to the field of great power competition.

Three scenarios within the arena of great power competition will provide useful models for examining key aspects of American strategic culture thinking and practice: future war with a near-peer power; proxy conflict played out by, with, and through third-party partner forces; and authoritarian advances in ideological warfare made possible through the use of sophisticated digital technologies.

\section{Preparing for Future War: Battling a Near-Peer Power}

When considering the prospect of future peer-to-peer conflict, the good news is that American strategic culture is rife with raw enthusiasm for preparing for conventional war. It is, however, a very particular vision of conventional war. A significant amount of scholarly work has documented the United States' preferred way of war favors wars of annihilation against conventional enemies that can be accomplished in short time frames by employing lavish firepower in "an aggressive hunt for the main body of the foe." ${ }^{5}$ The several prominent voices who have challenged this characterization focus on the U.S. military's wealth of historic experience with unconventional ways of war and the ability of its fighting force to adapt and competently execute them. ${ }^{6}$ These irregular warfare experiences, however, have not shifted the conventional preferences that dominate U.S. strategic culture. ${ }^{7}$ 
The U.S. Army has considerably more practice with unconventional warfare than the conventional sort but has maintained a steady march toward excellence in conventional form and function since its frontier days. Even while fighting Native Americans that they considered to be "master[s] of guerrilla warfare," the U.S. Army failed to cultivate doctrine, training, or any professional literature that would reflect lessons learned in its struggles against the continent's indigenous people. ${ }^{8}$ Internal battles with local tribes were "beneath the soldiers' vocation." ${ }^{\prime \prime}$ As the Army's irregular fights at home and abroad multiplied, the frequency of practice did little to dispel the general disdain toward low-threshold, often inconclusive missions. Robert M. Cassidy, in his historical study of U.S. peacekeeping and counterinsurgency experiences, quips: "It is somewhat ironic, revealing, and disquieting that an institution with more history and experience fighting irregular conflicts of limited intensity than total wars without limits, would have its core culture so profoundly influenced by [William T.] Sherman, [Emory] Upton, and the World War II experience." ${ }^{10}$

Preference for conventional conflict is not terribly unusual for a national military - there is significant advantage in being able to recognize one's enemy by virtue of their uniform. Conventional conflict is particularly attractive to the United States as a superpower, however, as it plays to key U.S. strengths in materiel kit, logistical dominance, and technological superiority. ${ }^{11}$ Preference notwithstanding, future U.S. conflict with a great power competitor is likely to be muddied with nontraditional elements of hybrid warfare and be fought with local partners across the territory of some unfortunate third party. Without a conscious decision from strategic planners that the past will not be prologue, U.S. operations will likely fall along the traditional pattern characterized by Eliot A. Cohen in which "[the] American proficiency at imparting technical skills is matched only by American insensitivity to local conditions." 12

\section{Reliance on Technological Overmatch}

Technological superiority has long been the signature of modern American combat form, and yet strategic warnings against an overreliance on technology have been sounding for some time. ${ }^{13}$ Williamson Murray cautions that " $[t]$ he greatest danger for the United States in the coming century is that the American military will possess self-satisfied, intellectually stagnant cultures that believe they have found the technological lodestone." ${ }^{14}$ It is interesting that Murray made his claim in the same year that the now infamous Millennium Challenge 2002 exercise seemed to prove it. Set up as a war game to test some of the technologies designed to support the Pentagon's network-centric approach to warfare, the game was won almost before it began by the inventive low-tech tactics of Lieutenant General Paul Van Riper. Leading the team representing the enemy, Van Riper killed his own radio communications in favor of mo- 
torcycle messengers and light signals, then fitted patrol boats, pleasure boats, and small aircraft with missiles and explosives. His preemptive kamikaze attack neutralized 16 Navy ships and "killed" thousands. For all intents and purposes, the game was over. Frustrated by Van Riper's low-tech and unsportsmanlike methods, the game's orchestrators called for a scripted do-over in which Van Riper's enemy force was forced to follow a set protocol, which allowed it to be decimated by high-tech U.S. forces. ${ }^{15}$ The means of war privileged in the Millennium Challenge 2002 serve as an extreme example of the American preference for dominating through technology rather than human ingenuity-a vulnerability that could be exploited by near-peer competitors who are already actively leveraging warfighting shortcuts to close the gap between the military strength of the United States and their own forces.

Furthermore, American technological superiority may soon be eroded as a distinct advantage. Near-peer powers are quickly catching up to some of the Pentagon's most sophisticated assets, which means that even proxy fights are likely to be fought with their sponsor's far more advanced weaponry. In addition, the entry threshold for military technology continues to drop, enabling traditionally weak or nonstate actors, including lone-wolf individuals, to punch at an increasingly higher technological weight. ${ }^{16}$ Even America's most sophisticated technological platforms, such as the Lockheed Martin F-35 Lightning II, are vulnerable to the advancing cyber expertise of a growing number of belligerents. The networked cyber systems that provide the F-35's much vaunted data-rich view of the battlefield also renders this platform particularly vulnerable to indirect hacks through one of its supporting systems. ${ }^{17}$

The growing utility of additive manufacturing (3D printing) also erodes some of the logistical advantages traditionally wielded by the United States and will complicate future strategies to interdict weapons. In not-so-future conflict areas and civilian zones, a significant number of armaments will be manufactured in real time and on-site. ${ }^{18}$ In this increasingly technologically leveled arena, the great power that best understands the human terrain across which it is fighting will possess advantages in increasing friction for its enemy and decreasing it for itself. Cross-cultural competence skills, informed by an understanding of regional history, will be key warfighting assets.

\section{Underinvesting in Cultural Competence}

Despite these stakes, a deeply internalized commitment to the education and training necessary to achieve proficiency in cultural analysis will not come easily to the American defense establishment, in large part because it is not valued in the wider national community that it serves and from which its personnel are drawn. Americans have inherited a number of habits of mind that successfully advanced the prosperity of a young immigrant nation but have led to an 
undervaluing of cultural and historical analysis within U.S. strategic culture. A forward-leaning optic and near dismissal of the past is a habit of mind documented across the American population from its earliest days. D. W. Brogan, a British observer of American culture writing in 1944, argues that American pioneers came by this trait honestly. Very little of their survival depended on a study of Old World history. The forward-looking and problem-solving approach required in the making of America took "extraordinary energies" and cultivated a peculiarly American attitude, which refrains from looking back. ${ }^{19}$ Writing 20 years later, Stanley Hoffmann was more blunt, arguing that the American obsession with progress has resulted in a perspective that is the equivalent of "historical virginity." ${ }^{20}$ Americans value novelty over tradition and often point out change in their local settings as markers of progress. ${ }^{21}$ A quip attributed to the quintessential American problem solver, Henry Ford, sums up this mentality: "History is more or less bunk. It's tradition. We don't want tradition. We want to live in the present and the only history that is worth a tinker's dam $[$ sic $]$ is the history we made today." 22

Contemporary scholars of American strategic culture and ways of war argue that "ahistoricism" continues as a serious deficit within U.S. decision-making circles. ${ }^{23}$ An American public that is largely uninterested in historic knowledge tends not to prioritize it when electing officials. ${ }^{24}$ Public figures are rewarded instead for experience-based common sense and forward-looking ambition. ${ }^{25}$

Americans live in comfortable ignorance about other lands due to a combination of both cultural insularity and native enthusiasm about the American way of life. Samuel P. Huntington argued in 1957 that insular thinking is deeply rooted in American philosophies of liberalism, which focus inward on domestic affairs and largely ignore the foreign sphere. ${ }^{26}$ Oliver M. Lee argues that this trend has continued to the present day. The American brand of individualism focuses first on the self, then in concentric circles moving outward-family, local community, and to some extent the nation. Little interest is reserved for the wider world beyond. ${ }^{27}$

It is perhaps no surprise, then, that research conducted by Edward C. Stewart and Milton J. Bennett, authors of the seminal classic American Cultural Patterns, finds that most Americans possess "a cultivated ignorance of other nations," harboring biases that assume mutual similarity and gross oversimplifications. ${ }^{28}$ This mindset neither a product of malice nor is it terribly unique to Americans; but it is particularly consequential when it dominates the foreign and security policy decision making of a world superpower.

For both of the United States' primary great power competitors-Russia and China-Phase Zero preparation includes a studied understanding of the populations subjected to their influence operations. Russia's media and information operations outlets, for instance, invest significant effort in understand- 
ing the political and social landscape of intended targets. The resultant cultural intelligence yields success in exploiting social sensitivities and grievances within the domestic populations of its competitors while steadily building communities of trust that will be more receptive to Russian messaging. ${ }^{29}$ In addition, English language classes are mandatory and American history classes are encouraged across many Chinese and Russian educational institutions. ${ }^{30}$

Looking forward, U.S. forces may reasonably expect that they will be fighting a near-peer power across theaters in which the adversary has already made significant inroads with the population. Understanding the depth and breadth of American disinterest in other cultures and recognizing it as a byproduct of historic national experience may enable strategic planners to identify and override instincts that put cultural training first on the chopping block when defense budgets experience stress. The cultural priming that consistently underprioritizes cultural education and training in the U.S. defense establishment is not only poor strategic practice; it is a potentially serious liability in the face of looming conflict with culture-smart adversaries.

\section{By, With, and Through: Great Power Competition and Proxy Warfare}

Great power competition short of war-known variously as gray zone warfare, hybrid warfare, political warfare, and asymmetric warfare, among other labels is intrinsically revisionist, whether employed by great power competitors or by nonstate actors. These actors seek to shift the status quo in ways that would harm U.S. interests without triggering a direct confrontation with its military forces. ${ }^{31}$ Some of the core takeaways for advancing and protecting U.S. interests in gray zone competition echo the points of the previous section: investments in understanding local contexts and culture will yield strategic advantages. The relationships the U.S. forges with local partners will be key to achieving U.S. objectives. Leaders within the U.S. special operating community are clear about the population-centric nature of gray zone mission sets already underway, and pursue these almost exclusively by, with, and through partner forces. ${ }^{32}$

In addition to prioritizing language and culture training, U.S. strategic planners and warfighters engaged in gray zone warfare will also benefit from a clear-eyed recognition of a few U.S. strategic cultural predispositions. These include a hyperorientation to problem solving, a devotion to effort optimismthe belief that through hard work one can achieve anything-and an obsession with quantitative metrics of success that are likely to impact the success of relationships with local security forces and the host populations from which they are drawn. 


\section{Americans as Human Do-ings}

In the early 1990s, a Russian student_fresh from the recent collapse of the Soviet Union-arrived at the college campus in Utah where the author was a junior instructor. After several weeks of enthusiastic welcoming and wellintended congratulations from her American peers ("How does it feel to be free?!"), she volunteered to give a comparative presentation on Russian and American culture. Her presentation began with the blunt statement, "Americans are not human beings." She continued with: "Americans are human doings. They don't know how to be." Her pithy, jarring, and strikingly insightful assessment of American culture tracks with the observations of historians and ethnographers, and echoes primary themes across U.S. military doctrine.

Problem-solving is key to American identity--being a problem-solver is both a requirement for most occupations and an admired personal trait. For Americans, it is also perceived to be the primary purpose of human activity. ${ }^{33}$ The military puts this impulse on steroids. The bias for action championed by U.S. Marines is one in favor of problem solving. Former Air Force pilot John R. Boyd's OODA (observe, orient, decide, act) loop tempo, which forms the core of the Corps' warfighting doctrine, is the ability to solve problems at a faster rate than the adversary to gain the initiative. Within this doctrine, overreaction can be forgiven - "errors by junior leaders stemming from overboldness are a necessary part of learning." But inaction cannot: "[O]n the other hand, we should deal severely with errors of inaction or timidity." ${ }^{34}$

As human do-ings, Americans are comfortable with trial and error as a learning method and tend to venerate heroes who epitomize the innovative and action-oriented problem solving from the frontier past. ${ }^{35}$ An American's sense of identity is rooted in their occupation: one is what one does. ${ }^{36}$ With a value orientation firmly fixed on demonstrated activity, Americans tend to exude "busy-ness" as a status symbol. The fast pace of American life ("hurry sickness") is not new to this century or to the previous one. As early as the 1830s, Alexis de Tocqueville remarked on the excessive rushing about in American life. ${ }^{37}$ Two hundred years later, Americans remain incessantly on the move. ${ }^{38}$ Marines capitalize on American haste and take it further. Tempo and raw speed in the delivery of lethal effects is a core attribute of Marine combat doctrine: "Speed is a weapon." 39

The American preference for fast action means that tasks that require patience, restraint, and caution run counter to preferred American instincts. Working at the pace of local forces to execute key operations or with local officials responsible for civic action projects, the delivery of humanitarian aid, or the establishment of functioning governance can tax the patience of American diplomats and military forces. In response, Americans typically set a deadline. Americans possess near mythical regard for deadlines as a means for increasing 
efficiency and accelerating progress, and they expect others to do the same. ${ }^{40}$ When the threat of a deadline is insufficient to fast-track local action, the result is often a breach in the local relationship in favor of the efficiency of doing it ourselves. When the achievement of U.S. strategic objectives involves local sustainment of security measures or public services, the preferred American pace tends to backfire.

The action-orientation of U.S. forces may also result in blind spots for military intelligence. Americans assign status based on demonstrated personal achievement and look for it in local leaders, a habit of mind that may cause them to overlook the import of key influencers within relationship-based societies who derive status from other sources, including family ties, religious position, or knowledge of local history. ${ }^{41}$ In addition, impatience with the time required to research and assess the complex sociocultural angles of problem sets can leave American intelligence officers and planners easy prey to peddlers of single-solution concepts. ${ }^{42}$

\section{Effort Optimism and the Engineering Fix}

The action orientation of U.S. problem solvers is fueled by a particularly attractive trait within the American ethos-an unsinkable optimism. Expectations for success permeate American life and U.S. national security documents. ${ }^{43}$ Brogan points out that an outsized belief in one's own abilities and the possibility of success against long odds were the survival tools of the continent's earliest European settlers; intrepid enough to brave life in the New World, their optimism became a national brand. Within the "religions of economic and political optimism" Brogan observed, "dissent, especially continuous pessimistic crabbing" was "near to treason." ${ }^{44}$ Scholars across the decades have continued to note this theme, citing "effort optimism" as a key American value. ${ }^{45}$

Colin S. Gray points out the implications for foreign and security policy: "[I]t is quintessentially American to be optimistic and to believe that all problems can be solved, if not today, then tomorrow, and most probably by technology." 46 The result, Gray cautions, is an American formula that can substitute optimism for hard-nosed analysis: "The problem-solving faith, the penchant for the engineering fix, has the inevitable consequence of leading U.S. policy, including its use of armed force, to attempt the impossible." ${ }^{47}$ Leonard Mason's review of a significant body of anthropological work on American culture provides support to Gray's claim. Accustomed to a history of success in mastering the physical environment, Americans "are equally confident that undesirable social conditions can be remedied just as easily and are confused when such proves not to be the case." ${ }^{8}$

In the gray zone warfare context, applying an effort-optimism engineering fix to training partner security forces can result in extreme frustration on the 
part of U.S. forces and a concomitant souring of its relationship with local partners. American cognitive patterns emphasize linear thinking and causal chains in which situations are diagnosed as a series of isolated, solvable problems rather than as a web of complex dynamics and relationships. ${ }^{49}$ This orientation creates an exaggerated sense of control over the environment and a perception of independence from the decisions and actions of others. ${ }^{50}$ Operating through this lens, U.S. forces tend to fixate on their own training efforts as key to crafting effective local fighting forces rather than examining indigenous "will to fight" factors over which they may have limited control. ${ }^{51}$ In publications assessing local security force failings in Iraq, U.S. Marine officers focused on improving their own training regimen as a remedy to lackluster indigenous fighting spirit rather than engage in serious analysis of their recruits' incentives to fight for what American's perceived as core objectives. Disappointing performance was attributed to improper training - a situation that could be remedied with education, hard work, and resources - not examined as a manifestation of local circumstances and incentives. Myopic analysis of this sort-fueled by a can-do spirit-does not help alleviate frustration with local force performance or produce the insights necessary to build or repair strategically important relationships. $^{52}$

When competing for influence against an aggressive power like Russia, whose military doctrine holds a core place for preemptively and continually shaping the "cognitive battlespace" of contested areas, an overdeveloped focus on the delivery of excellent training as the key to successful local partnerships risks underestimating the effectiveness of targeted influence operations aimed at shaking the commitment of partner forces and populations. ${ }^{53}$ Strategic and operational leaders may further be tempted to assume that increased U.S. efforts or resources offer a direct, linear solution to winning back the loyalties, or at least shared interest, of local partners from strategic adversaries' encroachment. Unfortunately, this blind spot is only compounded by the American proclivity for measuring operational success, including engagement with proxy forces, in numbers.

\section{Obsession with Quantification}

The compelling need to quantify the world, and experiences within it, is deeply rooted in the American psyche. Stewart and Bennett point out that the "[c]riteria that define success and failure [in the United States] are statistically measured, as are amounts of work, levels of ability, intelligence, and quality of performance." The number of minutes spent with a U.S. president typically conveys the importance of their guest to the press. ${ }^{54}$ Americans find comfort in quantification because behavior that is quantified becomes objectified and is perceived as amenable to human control. ${ }^{55}$ 
In the foreign and security policy arena, measuring the successful growth of strategic relationships, the stabilization of fraught societies, and progress toward political objectives can be difficult, so Americans often default to the aspects that can be most easily counted. Even in population-centric warfare-where relationships are key—enemy dead and weapons confiscated are two typical measures of operational success. Pressed for other measurements, U.S. forces often report on American inputs - the number of hygiene kits distributed, lengths of road built, cash distributed, and patrols run-treating them as successes in their own right, as evidence of strategic progress regardless of whether these inputs have significantly advanced the political goals they are meant to achieve. The same pattern is repeated for partner security training. Reports to military superiors emphasize the countable aspects of foreign internal development: number of local forces participating, hours spent on marksmanship, drills run, and certificates of completion signed.

U.S. Marines have the particular fortune of possessing the most excellent piece of modern doctrine in print. Warfighting, Marine Corps Doctrinal Publication 1 (MCDP 1), addresses a number of American default settings, including the passion for countable things, and issues the appropriate caution: "Although material factors are more easily quantified, the moral and mental forces exert a greater influence on the nature and outcome of war." ${ }^{56}$ Moral and mental forces-the cognitive realm-sit at the center of twenty-first century contests of influence. Aspects of the cognitive realm are difficult to measure and the complexity of the task may tempt commanders to continue to default to superficial indicators-American material inputs or the efforts of its own forces-when assessing the health of partner relationships or the efficacy of U.S.-supplied training. Without a concerted effort to forge new assessment tools, American habits of practice are destined to remain dangerously sophomoric and unreliable as strategic indicators.

Creative and reasonably credible measures of strategic progress in population-centric warfare settings are not only possible; some have already been field tested in pockets of the U.S. force. During the initial years of the Iraq War, Marines defaulted to measuring mission progress by counting insurgents killed and weapons found, but as the counterinsurgency campaign matured and Marine officers in al-Anbar Province saw success in their outreach to tribal leaders, they recognized that their standard reporting metrics would neither capture the progress they were making nor incentivize the right kind of effort from the warfighters under their command. ${ }^{57}$ These officers implemented innovative measurements that tracked more reliable indicators of strategic progress: the number of recruits volunteering for American training and the volume of intelligence offered by the population. Colonel Julian Dale Alford proved even more creative: while commanding in al-Qaim, he ordered his Marines to tally 
the number of dinner invitations they received. Dubbed "eats on streets," his count acted as a barometer for the rapport being built with the community. ${ }^{58}$

Meaningful measures of operational and strategic success are particularly critical in the blurred battlespaces of gray zone conflict. The United States remains engaged in sharp conflict with Iran's proxies across the Middle Eastan aspect of gray zone competition unlikely to abet in the near term. It will be through local partners that the United States seeks to achieve its objectives and roll back Iran's ambitions for regional hegemony. Tehran's patient cultivation of proxy forces that share its worldview, and support for social-welfare institutions that curry support from the wider public are gray zone obstacles already significantly entrenched. ${ }^{59}$ Confronting Iran's agenda in the region will require analytical tools that widely account for local conditions, complex loyalties, popular worldviews, and incentives that resonate with local partner forces. Measuring success against this complex landscape requires surmounting American instincts to default to superficial quantitative metrics. Ben Connable, in a thoughtful piece written for the Rand Corporation, offers a selection of alternative assessment models that are both qualitative and quantitative in nature and leverage the wealth of lessons learned across recent U.S. experience with population-centric warfare. ${ }^{60}$ His analysis and findings demonstrate that despite its traditional proclivities, the United States is in a particularly advantageous position, given its wealth of experience in partnering with local forces during both active conflict and in peacetime to advance beyond its quantitative-centric default setting and forge qualitative assessment tools that advance U.S. metrics for assessing local loyalties and will to fight.

\section{Great Power Ideological Competition: Authoritarian Ambitions}

A third frontier over which the future of great power competition is likely to play out is in the contest of ideology, as the U.S. model of democratic governance faces increasing pressure from the proliferation of authoritarian and protoauthoritarian regimes. Strategic competitors solidifying their own unilateral rule at home will continue to seek to exploit domestic turmoil abroad and leverage political and economic upheaval to expand their own spheres of influence through well-developed weaponized narratives and psychological warfare campaigns undermining Western and Western-leaning governments. ${ }^{61}$ Regimes seeking to stabilize governance at home may be attracted to the promise of advanced Chinese surveillance systems designed to augment state control of citizen behavior. American cultural presets-particularly an evangelical enthusiasm for American-style democracy and a deep faith in the power of material generosity to accomplish strategic goals_-represent dangerous blind spots that may prevent U.S. decision makers and strategic planners from identifying or 
properly weighting great power competitors' advancing efforts to promote authoritarianism abroad and undermine the foundations of U.S. leadership and democratic governance across U.S. allies and partners.

\section{Blind Spots in the American Zeal for Democracy}

Although messianic tendencies toward exporting American political processes and values tend to be a hallmark of U.S. foreign policy today, early twentiethcentury Americans were not so sure about their portability. Europeans were viewed as "not yet ready" for American-style democracy and Central and South Americans were regarded as not sufficiently civilized. ${ }^{62}$ As the American experiment in democracy gained momentum in power and status, its population came to see its virtues as universal and its adoption as inevitable. ${ }^{63}$ Moved by this perceived eventuality, it became part of the American default setting to proselytize the American model at every opportunity. ${ }^{64}$ Americans want to extend to others those virtues prized in their own culture: a democratic setting that advances individual worth, justice, and fair play, and offers the chance to realize the American dream-individualism, equal opportunity, and the right to pursue happiness. ${ }^{65}$

For Americans, it is difficult to conceive of a future in which authoritarianism emerges as the dominant international model. American policy makers and the public alike regard movements toward democratic governance to be an ineluctable and natural process of political evolution, one that will continue to mend relations between nations and result in international prosperity and stability. The normal march forward for humanity is believed to be advancement toward a better life for a consistently expanding percentage of the global population. ${ }^{66}$ The basic sentiments that underpin this American view are captured in academic literature as "modernization theory," which held sway as a dominant paradigm in the 1950s and 1960s and made a modest comeback in the social sciences of the 1990s. As noted by Francis Fukuyama, "If one were to sum up the Americanized version of modernization theory, it was the sunny view that all good things went together: Economic growth, social mobilization, political institutions, and cultural values all changed for the better in tandem." ${ }^{67} \mathrm{Al}$ though modernization theory has fallen into ill repute within the scholarship of the academy, the basic tenets of this theory remain alive in the mental models of America's leaders and its citizens. Movement away from, rather than toward, democratic practice is perceived as out of the natural order and are difficult for Americans to anticipate, consider probable, and adequately prepare to accomplish. Washington reacted to Moscow's 2014 invasion of Crimea, for instance, with shock and outrage that Russia would engage in an act "on the wrong side of history." 68

One of the consequences of these combined assumptions is an ethnocentric 
tendency toward viewing the populations of undemocratic regimes as "underdeveloped Americans" who have been stymied in some way in their natural progression. ${ }^{69}$ Americans believe that if liberated from their dictators and given the material resources to build a new life, the natural inclination of most people would be to gravitate toward democracy. American support for wobbling partner governments, therefore, has relied heavily on American material generosity and the deployment of its military force: two approaches that are not without their successes in history, but are likely to fall short in an era of technologydriven incursions against democracy.

\section{Material Fixes to Immaterial Problems}

Leaning on its default setting for the engineering fix, U.S. policy makers tend to perceive struggling partner governments as a problem to be fixed or, if the government has been pushed out in a regime change, an item to be built. U.S. nation-building efforts surge forward with native optimism, undiluted by a knowledge of history that would reveal the limits of a foreign power in doing so. Consequent failures tend to be explained in the American mind as products of insufficient resources or insufficient U.S. effort. ${ }^{70}$

Limited in their understanding of other cultures, Americans tend to lean on instincts of material generosity to forge relationships and provide support to governing structures. Drawing from the rich economic treasure of the United States, diplomatic and military personnel dispense humanitarian aid, build schools, and improve infrastructure to advance democracy and indigenous life. Anthropologists Edward T. and Mildred Reed Hall hold up the United States as genuinely distinctive in this regard, declaring that American material generosity is "matched by no other country we know." 71 Through gifts of resources and infrastructure, Americans aim to win friends over to the virtues of democracy and accelerate the social and economic progress required for stability. Brogan, among others, tracks the origins of the American fixation on material advancement to the Protestant Reformation and its spread through American religious circles. The result was a cultural conflation of prosperity and virtue. ${ }^{72}$ Belief in the positive morality of material success propelled the American economy forward, enabling robust economic growth and unparalleled logistical excellence. Americans typically measure their own national health through daily tracking of fiscal and material indicators.

Material investments are often deeply appreciated by the populations who receive them and in some critical cases have achieved the strategic objective of shoring up democracy. The material investments of the 1948 Marshall Plan were not insignificant in the effort to strengthen fragile democracies in postWorld War II Europe, a model that continues to resonate with Americans today. The U.S. experience since that era has resulted in some negative lessons learned 
concerning the savvy application of material resources. Resources aimed specifically at the population-medical services, food supplies, hygiene kits, soccer balls, and the like-produce sincere gratitude when addressing a local need. A lush dispersal of funds and projects, however, can have unintended, counterstrategic effects. In some cases, the more generous the dispersal of goods, the more destabilizing the effects may be. A sudden injection of resources can create destabilizing winner/loser dynamics, fuel corruption, inadvertently supply the underground economy that feeds disruptive actors, destroy the fledgling profitability of local businesses, and even create perverse incentives among key actors to maintain a status quo of insecurity to remain on the receiving end of a steady flow of funds. ${ }^{73}$

Furthermore, when these investments are made without regard for local preferences or the ability of local resources to sustain the project beyond a U.S. force presence, they stand as a testament to wasted effort, or worse, harm local dignity and have a souring effect on U.S. relationships. A Marine captain of the Vietnam era offered sage insight concerning the overwhelming material gifts he saw being dispersed around him: "Generosity which cannot be returned breeds hostility, not affection." " The fixation on winning local gratitude rather than amplifying local dignity can also lead America's citizens to become disillusioned and resentful when they believe their material gifts and well-meaning efforts are not appreciated. ${ }^{75}$ These negative sentiments can become vulnerabilities exploited at home by the political opposition, often resulting in a swell of public opinion to cut aid short and abandon the regime to its own devices. ${ }^{76}$

As recent U.S. efforts in nation-building have made clear, it is the character and policies of the host government—not the resources or will of foreign forces - that is most determinative in winning the political support of the wider population and establishing the political legitimacy necessary for democratic governance. American forces can neither "gift" democratic legitimacy to a dysfunctional or unpopular indigenous government, nor are its material investments sufficient to supply freedom from violence and stability in everyday life.

The combination of these American default settings — an assumption of the natural magnetism of democratic governance, and a belief in material benefits as the surest means to get there-are currently being challenged by the United States' most powerful competitors. Two of the most critical threats to democratic leadership are Russia's determined efforts to undermine Western-style governance through hostile social manipulation and China's advancing export of digital authoritarianism.

\section{Great Power Challenges to U.S. Leadership and the Democratic Model}

Russian efforts to sow discord, cast doubt on the legitimacy of democratic gov- 
erning structures, and manipulate attitudes within targeted populations has been explored widely in literature and falls under a number of labels. Rand authors Michael J. Mazarr et al. make a sound case in favor of "hostile social manipulation" as an umbrella term that captures the core Russian intent. As this team of researchers carefully documents, the wide variety of Russian attempts to manipulate the attitudes and thinking of foreign populations has resulted in a mixed record. In the case of the United States, it is unclear whether recent Russian attempts to shape the American cognitive realm did much more than modestly accelerate attitude trajectories already in motion. ${ }^{77}$

Russia's mixed record and willingness to fail in repeated forays of trial and error may cause Western analysts to miss a critical takeaway: Moscow has clearly demonstrated both national will and national long-term investment in mastering the art of manipulating the cognitive realm. Russia's whole-of-society approach to improving its hostile social manipulation tactics promises to become even more worrisome as its security professionals, corporate mavens, and entrepreneurial civilian contractors refine their approaches through new technological platforms. Emergent digital technologies, including increasingly advanced uses of machine learning and artificial intelligence, have the potential to anticipate audience preferences and fine-tune Russian messaging for maximum impact against particular demographics. Russia's determination to triumph in information operations is firmly fixed; for Moscow, success here is considered existential. Russia has long viewed U.S. public narratives - including those promoting human rights, democracy, and a U.S.-led global order-as conscious attempts to undermine and overturn the Russian regime. Dominating the cognitive domain, in its view, is the only way to protect the longevity of the Russian state. $^{78}$

American confidence in the self-evident benefits of its own governing paradigm combined with a historically unfounded certainty regarding democracy's inherent stability may inhibit U.S. public investiture in the research, personnel, technologies, and defense focus necessary to protect democratic governance at home and provide something beyond token material support to partners abroad. Defense professionals pursuing information operations on behalf of U.S. interests acknowledge that their mission is understaffed, under budgeted, and regarded by leadership as peripheral to more serious U.S. defense objectives. They, alongside the scholars tracking the growth and development of the Russian information offensive, sound consistent warnings regarding the potential strategic consequences of continuing in this vein.

An American whole-of-society approach that would mirror the effort being mounted by Moscow is not likely to be created in the near term. Bridges between the public and private sector would need many more connective planks than currently exist - and more than perhaps should exist in a healthy democ- 
racy. Nevertheless, smaller steps toward protecting the domestic infosphere and countering Russian aims are possible. U.S. leadership in both the public and private sectors would benefit from examining the characteristics of those populations outside of the United States or those demographics within it that have proved particularly resilient to Russian efforts to sow discord and undermine faith in democratic institutions. Public investment in understanding what went right in these circumstances and which lessons might be learned and duplicated represents a reasonable first step. Exploring the fundamental components of resilient communities - a subject that has captured interest within pockets of both the U.S. public and private sectors - and the range of effective means to strengthen resilience where it is lacking will provide insights that advance U.S. thinking on the types of support that may be offered to partner nations. Investments of this sort cannot come too soon; attaining domestic stability is a priority for most all governing regimes, and China is offering a high-tech authoritarian remedy.

U.S. confidence in the basic attractions of the democratic model across the globe may be inhibiting the ability of political and corporate leaders to fully appreciate and react to the implications of China's evolving social credit system (SCS) — a set of pilot programs that employ sophisticated technology to track, surveil, and impose positive or negative consequences in response to the microactivities of its citizenry. China's SCS technological package has the potential to become a lucrative export, and if used by autocratic customers with the same deft skill that China has employed, it will quash internal protest movements and significantly advance the longevity and stability of authoritarian regimes.

China's diverse digital dictatorship toolkit is not the only one of its kind, but it is the most advanced. China's internal use of "dataveillance" systems reaches into small details of daily life_-awarding citizens higher individual social credit scores for volunteer work and donating blood, drops in scores for jaywalking, playing music too loud, or walking a dog without a leash — to shape public behavior. ${ }^{79}$ Access to public services including transportation, financial loans, and advanced education are contingent on appropriately high social credit scores. American assumptions that such invasive practice would meet with revolt are misplaced. Most Chinese citizens accept the trade-off and value what they perceive to be the promotion of honest dealings in society. ${ }^{80}$ The lack of backlash from within China has allowed Beijing to market the attractions of its dataveillance platforms to its widening circle of economic partners, particularly through the Belt and Road Initiative. The foreign proliferation of this technology has consequences for human rights and for U.S. leadership: it represents a global movement away from philosophical alignment with narratives of democracy and closer to those promoted by Beijing. ${ }^{81}$

When considering policy that might counter the growing threats to de- 
mocracy, it is worth noting that the record of human history indicates a strong preference for stability and predictable living over concerns about personal liberty. Regimes struggling with domestic chaos or bouts of violence-even those who are friends of the United States_-may welcome Chinese advances in digital authoritarianism as a means of getting their houses in order. The application of dataveillance authoritarianism by new national customers in Africa, the Middle East, and beyond may not meet with the stiff resistance the United States expects if it is seen as effective at subduing disruptions to everyday life. The normalization of this technology has implications for international standards and the long-term viability of the democratic model. As China emerges as both the peddler and trendsetter in the tools of digital governance, its leadership in artificial intelligence and the digital age may pose the most serious threat to U.S. global leadership yet.

\section{Conclusion}

Competition with great power adversaries is unlikely to play directly to American strengths. It is being played against shrewd adversaries who are well acquainted with American advantages in warfighting as well as the deficits and vulnerabilities that history has opened to view. The salami-slicing tactics pursued by global competitors such as Russia and China-sometimes referred to as "exploiting ambiguities in deterrence" — are designed to take advantage of America's short attention span, four-year political cycle, and strong tendency to look to traditional measures of military power as reassurance for the continuance of American hegemony. ${ }^{82}$

The focus of the U.S. defense and security community on great power competition threatens to feed a preexisting penchant for conventional war that is too narrow in vision to adequately prepare the force for the next round of conflicts. Future war against a conventional foe is likely to take a strikingly unconventional form if fought across the population of a third-party nation. Recognizing our own cultural presets with more clarity will provide advantages in thinking strategically about civic as well as military action on the ground, prioritizing meaningful measures of progress toward long-term strategic goals, and avoiding the pitfalls of overestimating the salience, or existence, of U.S. technological overmatch vis-à-vis near-peer adversaries. Harvesting the readymade lessons from the last two decades of U.S. warfighting and building on these to successfully advance the local relationships with partners and allies that are critical to U.S. global success will require investments in history, culture, and lessons learned in irregular warfare-all efforts that will require a new set of best practices currently outside the comfort zone of American strategic culture.

Perhaps most importantly, the United States must lean forward in anticipating and countering efforts to undermine the society of democratic nations 
that form the scaffolding of the post-World War II international order. U.S. global leadership depends on its ability to model the advantages of democracy and to effectively convey strength and resilience to partner nations that are being actively courted by U.S. competitors. The American model remains an experiment-one that requires a citizenry educated to spot malign foreign influence operations at home and diplomatic and security practices that inspire a wide circle of friends and alliances abroad.

\section{Endnotes}

1. Linda Robinson et al., Modern Political Warfare: Current Practices and Possible Responses (Santa Monica, CA: Rand, 2018), https://doi.org/10.7249/RR1772.

2. Colin S. Gray, "Comparative Strategic Culture," Parameters 14, no. 4 (Winter 1984): 26.

3. Keith B. Payne, The Fallacies of Cold War Deterrence and a New Direction (Lexington: University Press of Kentucky, 2001).

4. Jeannie L. Johnson, The Marines, Counterinsurgency, and Strategic Culture: Lessons Learned and Lost in America's Wars (Washington, DC: Georgetown University Press, 2018).

5. Russell F. Weigley, The American Way of War: A History of United States Military Strategy and Policy (Bloomington: Indiana University Press, 1973); Victor Davis Hanson, Carnage and Culture: Landmark Battles in the Rise of Western Power (New York: Anchor Books, 2001), 22. Both Hanson and Echevarria note that this is not an attribute unique to the United States. Antulio J. Echevarria II, Toward an American Way of War (Carlisle, PA: Strategic Studies Institute, U.S. Army War College, 2004), 2; Robert M. Cassidy, Counterinsurgency and the Global War on Terror: Military Culture and Irregular War (Stanford, CA: Stanford University Press, 2008), 103, 115; James Kurth, "Iraq: Losing the American Way," American Conservative, 15 March 2004; Thomas G. Mahnken, "U.S. Strategic and Organizational Subcultures," in Strategic Culture and Weapons of Mass Destruction: Culturally Based Insights into Comparative National Security Policymaking, ed. Jeannie L. Johnson, Kerry M. Kartchner, and Jeffrey A. Larsen (New York: Palgrave Macmillan, 2009), 74, https://doi.org/10.1057/9780230618305_5; and Colin S. Gray, Irregular Enemies and the Essence of Strategy: Can the American Way of War Adapt? (Carlisle, PA: Strategic Studies Institute, U.S. Army War College, 2006), 11.

6. Antulio J. Echevarria II, Reconsidering the American Way of War: U.S. Military Practice from the Revolution to Afghanistan (Washington, DC: Georgetown University Press, 2014); Brian M. Linn and Russell F. Weigley, “'The American Way of War' Revisited," Journal of Military History 66, no.2 (April 2002): 501-33, https://doi .org/10.2307/3093069; and Max Boot, The Savage Wars of Peace: Small Wars and the Rise of American Power (New York: Basic Books, 2002).

7. Mahnken, "U.S. Strategic and Organizational Subcultures," 73.

8. Robert M. Cassidy, Peacekeeping in the Abyss: British and American Peacekeeping Doctrine and Practice after the Cold War (Westport, CT: Praeger, 2004), 93.

9. Deborah D. Avant, "The Institutional Sources of Military Doctrine: Hegemons in Peripheral Wars," International Studies Quarterly 37, no. 4 (December 1993): 415, https://doi.org/10.2307/2600839; and John A. Nagl, Learning to Eat Soup with a Knife: Counterinsurgency Lessons from Malaya and Vietnam (Chicago, IL: University of Chicago Press, 2005), 44.

10. Cassidy, Peacekeeping in the Abyss, 98.

11. Phillip S. Meilinger, "American Military Culture and Strategy," Joint Force Quarterly 46, no. 3 (2007): 81; Gray, Irregular Enemies and the Essence of Strategy, 46; Williamson Murray, "An Anglo-American Strategic Culture?" (paper prepared for the symposium 
Democracies in Partnership: 400 Years of Transatlantic Engagement, Williamsburg, VA, 18-19 April 2007), 152; and Jeffrey Record, The American Way of War: Cultural Barriers to Successful Counterinsurgency, Policy Analysis no. 577 (Washington, DC: CATO Institute, 2006), 5.

12. Eliot A. Cohen, "Constraints on America's Conduct of Small Wars," International Security 9, no. 2 (Autumn 1984): 169.

13. Colin S. Gray, "British and American Strategic Cultures" (paper prepared for the symposium Democracies in Partnership: 400 Years of Transatlantic Engagement, Williamsburg, VA, 18-19 April 2007), 49; Theo Farrell, "Strategic Culture and American Empire," SAIS Review of International Affairs 25, no. 2 (Summer/Fall 2005): 8, https:// doi.org/10.1353/sais.2005.0033/; Lawrence Sondhaus, Strategic Culture and Ways of War (London: Routledge, 2006), 60-61; Mahnken, "U.S. Strategic and Organizational Subcultures," 74; Sam C. Sarkesian, America's Forgotten Wars: The Counterrevolutionary Past and Lessons for the Future (Westport, CT: Greenwood Press, 1984), 5; and Peter Warren Singer, Insurgency in 2030: A Primer on the Future of Technology and COIN (Washington, DC: New America, 2019).

14. Williamson Murray, "Does Military Culture Matter?," in America the Vulnerable: Our Military Problems and How to Fix Them, ed. John F. Lehman and Harvey Sicherman (Philadelphia, PA: Foreign Policy Research Institute, 2002), 151.

15. Joe Galloway, “Rumsfeld's War Games," Military.com, 26 April 2006; and Julian Borger, "Wake-up Call," Guardian, 5 September 2002.

16. Singer, Insurgency in 2030.

17. Dreyton Shafer, Cyber Threats: Technically Savvy American Aviation's Blind (Logan: Center for Anticipatory Intelligence, College of Humanities and Social Sciences, Utah State University, 2019).

18. Singer, Insurgency in 2030.

19. D. W. Brogan, The American Character (New York: Alfred A. Knopf, 1944), 5.

20. Stanley Hoffmann, Gulliver's Troubles, or the Setting of American Foreign Policy (New York: McGraw-Hill, 1968), 110. See also Robin Williams, "Values and Modern Education in the United States," in Values in America, ed. Donald N. Barrett (Notre Dame, IN: University of Notre Dame Press, 1961), 66; and Gary Althen, American Ways: A Guide for Foreigners in the United States (Yarmouth, ME: Intercultural Press, 1988), $10-11$.

21. Brogan, The American Character, 136; Cora Du Bois, "The Dominant Value Profile of American Culture," American Anthropologist 57, no. 6 (December 1955): 1233, https://doi.org/10.1525/aa.1955.57.6.02a00130; Hellmut Lotz, "Myth and NAFTA: The Use of Core Values in U.S. Politics," in Culture and Foreign Policy, ed. Valerie Hudson (Boulder, CO: Lynne Rienner Publishers, 1997), 79; Maryanne Datesman, Joann Crandall, and Edward N. Kearny, American Ways: An Introduction to American Culture, 4th ed. (White Plains, NY: Pearson Education, 2014), 105; Edward C. Stewart and Milton J. Bennett, American Cultural Patterns: A Cross-Cultural Perspective, rev. ed. (Yarmouth, ME: Intercultural Press, 1991), 142-43; and Williams, "Values and Modern Education in the United States," 66.

22. Henry Ford, interview in the Chicago (IL) Tribune, 25 May 1916.

23. Murray, "An Anglo-American Strategic Culture?," 157. Murray makes the important point that ahistoricism is not a uniquely American trait: "[T]here are few military organizations that possess a culture that encourages the study of even the recent past with any thoroughness." Murray, "Does Military Culture Matter?," 140.

24. Sarkesian, America's Forgotten Wars, xii.

25. Stewart and Bennett, American Cultural Patterns, 158; and Lotz, "Myth and NAFTA," 80.

26. Samuel P. Huntington, The Soldier and the State: The Theory and Politics of CivilMilitary Relations (Cambridge, MA: Belknap Press, an imprint of Harvard University Press, 1957), 149.

27. Oliver M. Lee, "The Geopolitics of America's Strategic Culture," Comparative Strategy 27, no. 3 (2008): 276, https://doi.org/10.1080/01495930802185627. 
28. William Kincade, "American National Style and Strategic Culture," in Strategic Power: USA/USSR, ed. Carl G. Jacobsen (London: Palgrave Macmillan, 1990), 13, https:// doi.org/10.1007/978-1-349-20574-5_2; and Stewart and Bennett, American Cultural Patterns, 11.

29. James E. Hayes III, "Beyond the Gray Zone: Special Operations in Multidomain Battle," Joint Forces Quarterly, no. 91 (4th Quarter 2018): 64-65; and Robinson et al., Modern Political Warfare.

30. Du Hui, "The Globalisation of the English Language: Reflections on the Teaching of English in China," International Education Journal 2, no. 4 (2001): 126-33; Kingsley Bolton and David Graddol, "English in China Today: The Current Popularity of English in China Is Unprecedented, and Has Been Fueled by the Recent Political and Social Development of Chinese Society," English Today 28, no. 3 (September 2012): https://doi.org/10.1017/S0266078412000223; and Irina P. Ustinova, "English in Russia," World Englishes 24, no. 2, (2005): 239-51, https://doi.org/10.1111/j.1467971X.2005.00407.x.

31. James J. Wirtz, "Life in the 'Gray Zone': Observations for Contemporary Strategists," Defense \& Security Analysis 33, no. 2 (2017): 106-14, https://doi.org/10.1080/14751 798.2017.1310702.

32. Hayes, "Beyond the Gray Zone," 60-66; and Joseph L. Votel et al., "Unconventional Warfare in the Gray Zone," Joint Forces Quarterly, no. 80 (1st Quarter 2016): 101-9.

33. Stewart and Bennett, American Cultural Patterns, 32, 37, 68.

34. Warfighting, MCDP 1 (Washington, DC: Headquarter Marine Corps, 1997), 57-58.

35. Stewart and Bennett, American Cultural Patterns, 69, 155; and Datesman, Crandall, and Kearney, American Ways, 85-86.

36. Stewart and Bennett, American Cultural Patterns, 76. Emphasis added.

37. Datesman, Crandall, and Kearney, American Ways, 106.

38. Du Bois, "The Dominant Value Profile of American Culture," 1234; and Leonard Mason, "The Characterization of American Culture in Studies of Acculturation," American Anthropologist 57, no. 6 (1955): 1268-69, https://doi.org/10.1525/aa .1955.57.6.02a00160.

39. Warfighting, 39-40.

40. Mason, "The Characterization of American Culture in Studies of Acculturation," 1268; Stewart and Bennett, American Cultural Patterns, 74; and Edward T. Hall and Mildred Reed Hall, Understanding Cultural Differences: Germans, French, and Americans (Yarmouth. ME: Intercultural Press, 1990), 140-41.

41. Dima Adamsky, The Culture of Military Innovation: The Impact of Cultural Factors on the Revolution in Military Affairs in Russia, the US, and Israel (Stanford, CA: Stanford University Press, 2010), 75.

42. Colin S. Gray, "Out of the Wilderness: Prime Time for Strategic Culture," in Strategic Culture and Weapons of Mass Destruction: Culturally Based Insights into Comparative National Security Policymaking, ed. Jeannie L. Johnson, Kerry M. Kartchner, and Jeffrey A. Larsen (New York: Palgrave Macmillan, 2009), 224, https://doi. org/10.1057/9780230618305_14; Mason, "The Characterization of American Culture in Studies of Acculturation," 1268; Stewart and Bennett, American Cultural Patterns, 30-31; and Datesman, Crandall, and Kearney, American Ways, 106.

43. Maj Russell A. Moore, USMC, "Strategic Culture-How it Affects Strategic 'Outputs" (unpublished paper, Marine Corps War College, Marine Corps University, 1998).

44. Brogan, The American Character, 32-34, 74.

45. Du Bois, "The Dominant Value Profile of American Culture"; Datesman, Crandall, and Kearney, American Ways, 85-86; and Stewart and Bennett, American Cultural Patterns, 75 .

46. Gray, "British and American Strategic Cultures," 45.

47. Gray, "Irregular Enemies and the Essence of Strategy," 33.

48. Mason, "The Characterization of American Culture in Studies of Acculturation," 1269; and Datesman, Crandall, and Kearney, American Ways, 135.

49. Hoffmann, Gulliver's Troubles, 111; Kent C. H. Lam et al., "Cultural Differences in 
Affective Forecasting: The Role of Focalism," Personality and Social Psychology Bulletin 31, no. 9 (2005): 1296-1309, https://doi.org/10.1177/0146167205274691; and Adamsky, The Culture of Military Innovation.

50. Stewart and Bennett, American Cultural Patterns, 69; and Claude S. Fischer, Made in America: A Social History of American Culture and Character (Chicago, IL: University of Chicago Press, 2010), 210.

51. Ben Connable et al., Will to Fight: Returning to the Human Fundamentals of War (Santa Monica, CA: Rand, 2019), https://doi.org/10.7249/RB10040.

52. Lauren Mackenzie and Kristin Post, "Relationship Repair Strategies for the Military Professional: The Impact of Cultural Differences on Expectations and Applications," Marine Corps University Journal 10, no. 1 (2019): 128-41, https://doi.org/10.21140 /mcuj.2019100107.

53. Blagovest Tashev, LtCol Michael Purcell, and Maj Brian McLaughlin, "Russia's Information Warfare: Exploring the Cognitive Dimension," Marine Corps University Journal 10, no. 2 (2019):129-47, https://doi.org/10.21140/mcuj.2019100208.

54. Stewart and Bennett, American Cultural Patterns, 126.

55. Stewart and Bennett, American Cultural Patterns, 127.

56. Warfighting, 16.

57. LtCol Kenneth W. Estes, USMC, U.S. Marines in Iraq, 2004-2005: Into the Fray (Washington, DC: History Division, Headquarters Marine Corps, 2011); Bing West, The Strongest Tribe: War, Politics, and the Endgame in Iraq (New York: Random House, 2008), 101; and James A. Russell, Innovation, Transformation, and War: Counterinsurgency Operations in Anbar and Ninewa Provinces, Iraq, 2005-2007 (Stanford, CA: Stanford University Press, 2011), 62. For a look at both the American Army and Marines, see David Kilcullen, The Accidental Guerrilla: Fighting Small Wars in the Midst of a Big One (New York: Oxford University Press, 2009), 121.

58. Russell, Innovation, Transformation, and War, 65-67.

59. Michael Eisenstadt, Operating in the Gray Zone: Countering Iran's Asymmetric Way of War (Washington, DC: Washington Institute for Near East Policy, 2020), 14.

60. Ben Connable, Embracing the Fog of War: Assessment and Metric in Counterinsurgency (Arlington, VA: Rand, 2012).

61. Robinson et al., Modern Political Warfare; and Wirtz, "Life in the 'Gray Zone'," 109.

62. Marcus Cunliffe, "Formative Events from Columbus to World War I," in American Character and Foreign Policy, ed. Michael P. Hamilton (Grand Rapids, MI: William B. Eerdmans, 1986), 9.

63. Hoffmann, Gulliver's Troubles, 111; and Michael J. Williams, On Mars and Venus: Strategic Culture as an Intervening Variable in U.S. and European Foreign Policy (London: Lit Verlag, 2006).

64. Mahnken, "U.S. Strategic and Organizational Subcultures," 71. Phillip Meilinger notes this trend as it applies to Mexico in 1847; Cuba and the Philippines in 1898; Europe in 1918; Germany and Japan after World War II; and in Korea, Vietnam, Iraq, and Afghanistan in "American Military Culture and Strategy," 81; Morell Heald, "Foreign Relations, American Style," in American Character and Culture in a Changing World: Some Twentieth Century Perspectives, ed. John A. Hague (Westport, CT: Greenwood Press, 1979), 197-98; and Theo Farrell, "America's Misguided Mission," review of Democracy by Force: U.S. Military Intervention in the Post-Cold War World, by Karin von Hippel, International Affairs 76, no. 3 (2000): 3, https://doi.org/10.1111/14682346.00153.

65. Sarkesian, America's Forgotten Wars, 14-15; and Lotz, "Myth and NAFTA," 81.

66. Brogan, The American Character, 65.

67. Francis Fukuyama, "Samuel Huntington's Legacy: Why His Works on World OrderPolitical and Otherwise—Are Still Relevant Today," Foreign Policy, 6 January 2011.

68. David Usborne, "Ukraine Crisis: Putin Is 'On the Wrong Side of History' Insists President Obama," Independent, 4 March 2014.

69. Edward T. Hall, The Silent Language (New York: Premier Books, 1963), 9; and Althen, American Ways, xvi. 
70. Stewart and Bennett, American Cultural Patterns, 75.

71. Hall and Hall, Understanding Cultural Differences, 153.

72. Brogan, The American Character, 67; and Du Bois, "The Dominant Value Profile of American Culture," 1235.

73. Edwina Thompson, Winning "Hearts and Minds" in Afghanistan: Assessing the Effectiveness of Development Aid in COIN Operations: Report on Wilton Park Conference 1022 (Steyning, UK: Wilton Park, 2010), 11-14.

74. R. E. Williamson, USMC, "A Briefing for Combined Action," Marine Corps Gazette 52, no. 3 (March 1968): 43.

75. Stewart and Bennett, American Cultural Patterns, 108; and Hoffmann, Gulliver's Troubles, 101-2.

76. Minxin Pei, Samia Amin, and Seth Garz, "Building Nations: The American Experience," in Nation-Building: Beyond Afghanistan and Iraq, ed. Francis Fukuyama (Baltimore, MD: Johns Hopkins University Press, 2006), 68; Hall and Hall, Understanding Cultural Differences, 152; and Lee, "The Geopolitics of American's Strategic Culture," 280.

77. Michael J. Mazarr et al., Hostile Social Manipulation: Present Realities and Emerging Trends (Santa Monica, CA: Rand, 2019), https://doi.org/10.7249/RR2713.

78. Tashev, Purcell, and McLaughlin, "Russia's Information Warfare," 129-47.

79. Nicole Kobie, "The Complicated Truth about China’s Social Credit System," Wired, 7 June 2019; and Karen Leigh and Dandan Li, "How China Is Planning to Rank 1.3 Billion People," Washington Post, 4 June 2019.

80. Genia Kostka, "China’s Social Credit Systems and Public Opinion: Explaining High Levels of Approval," New Media and Society 21, no. 7 (July 2019): 1565-93, https:// doi.org/10.1177/1461444819826402.

81. Emilee Matheson, UAE Adoption of Chinese Digital Authoritarianism Threatens U.S. Security; Portends Soft Power Shift (Logan, UT: Center for Anticipatory Intelligence, Utah State University, forthcoming).

82. Wirtz, "Life in the 'Gray Zone'," 108. 